\title{
White-Eyed Orbital Blowout Fracture: A Retrospective Study of 22 Patients
}

\author{
Gyo Han Bae, Geun Woo Park, Tai Jung Park ${ }^{(D)}$, Woong Jae Noh, and Tae Young Jung (iD \\ Department of Otorhinolaryngology-Head and Neck Surgery, Maryknoll Hospital, Busan, Korea
}

\author{
White-Eyed 안와 외향 골절: 후향적 연구 22예 \\ 배교한 · 박근우 · 박태정 · 노웅재 · 정태영 \\ 메리놀병원 이비인후과
}

\author{
Received April 16, 2021 \\ Revised May 20, 2021 \\ Accepted June 3, 2021 \\ Address for correspondence \\ Tae Young Jung, MD \\ Department of Otorhinolaryngology- \\ Head and Neck Surgery, \\ Maryknoll Hospital, \\ 121 Junggu-ro, Jung-gu, \\ Busan 48972, Korea \\ Tel $+82-51-461-2692$ \\ Fax $+82-51-462-9419$ \\ E-mail handsjung@naver.com
}

Background and Objectives The study reports on the clinical experience of repairing white-eyed orbital blow out fracture through a retrospective study of various incidences of white-eyed orbital blow out fracture that resulted in different treatment methods and outcomes. Subjects and Method A retrospective study was performed on 22 patients with white-eyed blowout fracture who underwent operation between March 2009 and June 2019 at our clinic. Patients were divided into 2 groups by age: 6 to 12 and 13 to 18. A review of medical records included demographic data, cause of injury, preoperative symptoms, trauma to operation time and surgical outcomes including improvement of postoperative ocular symptoms and complications. Results The study population included 20 males and 2 female patients ranging from 6 to 18 years (mean, 14.2 years) of age. Fifteen of 21 patients with diplopia or limitation of eyeball movement showed a complete improvement of symptoms after surgery and $6(28.5 \%)$ had remaining symptoms. One patient had no ocular symptom, but had oculocardiac reflex including nausea and vomiting. Two cases were re-operated due to adhesion of graft material. There was one sinus infection related to the implant.

Conclusion This study shows that early reconstruction and release of incarcerated muscle within 5 days after trauma for white-eyed blowout fracture gives successful result that does not accompany major complications. All of the 22 patients who were operated for white-eyed blowout fractures had successful results.

Korean J Otorhinolaryngol-Head Neck Surg 2021;64(12):896-900

Keywords Orbital fractures; Prognosis.

\section{서 론}

안와 외향 골절은 외부의 충격으로 인해 안와 내벽 또는 하벽에 발생하는 골절로서, 성인에서는 비교적 흔하지만 소 아의 경우에서는 해부학 및 골조직 특성으로 인해 드문 것으 로 알려져 있다. 소아에서는 안와골의 높은 탄력성으로 인해 안구 주위 외상 후 안구 연부조직의 부종, 반상 출혈 등이 심

This is an Open Access article distributed under the terms of the Creative Commons Attribution Non-Commercial License (https://creativecommons.org/licenses/by-nc/4.0) which permits unrestricted non-commercial use, distribution, and reproduction in any medium, provided the original work is properly cited.
하지 않으나, 안와 외벽의 뚜껑문 골절(trapdoor fracture)로 인해 외안근이 골절편 사이에 감돈되어 안구 운동 장애와 함 께 통증, 안구심장 반사(oculocardiac reflex)가 나타나는데, 이를 white-eyed 안와 외향 골절이라 한다. ${ }^{1)}$ 이러한 whiteeyed 안와 외향 골절은 적정 시간 내에 수술적 치료를 통해 교정되지 않을 경우, 부분 혹은 영구적인 복시 및 안구운동 제한 등 합병증이 남을 수 있기에 일반적인 안와 외향 골절 치료와 달리 보다 조기에 수술적 치료가 수반되어야 한다. 희 귀한 질환의 특성상 국내에서 white-eyed 안와 외향 골절에 대한 연구는 거의 보고되지 않아, 저자들은 최근 10 년간 본원 
이비인후과를 방문한 소아 안와 골절 환자의 의무기록을 이 용하여 환자군에 대한 정보, 연령군에 따른 임상 양상 및 수 술시기, 수술방법에 따른 결과의 차이를 통해 최적의 치료 방 법을 알아보고자 하였다.

\section{대상 및 방법}

\section{대 상}

2009년 3월부터 2019년 6월까지 본원에서 전산화단층촬영 및 임상양상을 통해 진단된 white-eyed 안와 외향 골절 환 자들 중 정복술을 시행하고, 1 개월 이상 추적 관찰이 가능하 였던 22예를 대상으로 영구치가 완전히 분출되고 사골동이 성인과 같은 크기가 되는 12세를 기준으로 6 12세, 13 18세 2그룹으로 나누어 후향적으로 분석하였다. ${ }^{2}$ 내원 환자 전례 에서 시력검사, 안구운동검사, 안구돌출계측검사 및 안면부 전산화단층촬영을 시행하여 골절의 형태 및 부위를 확인하 여 수술적 접근 방법을 결정하였으며, 술후 5 일 이내 안면부 전산화단층촬영 및 안구운동검사, 시력검사 등의 안과 검사 를 통해 안와 골절 정복상태를 확인하였다. 수술은 가능한 조기에 시행하는 것을 원칙으로 하였으며, 안구운동장애나 복시를 호소하는 경우 또는 구역, 구토, 심계 항진과 같은 안 구심장 반사가 있는 경우를 수술 적응증으로 하였다.

\section{방 법}

수술은 모두 전신마취하에서 시행하였다. 일반적으로 속 눈썹 밑 경계선 2-3 mm 하방에 절개를 가한 후 안윤근과 안와 격막 사이를 박리하고 골막을 절개한 후, 골막하 박리 를 시행하여 골절 부위를 노출시켜 뚜껑문 골절과 외안근이 골절편 사이에 끼어 있는 것을 확인 후 부러진 골편을 교정하 였고, 생체흡수성 고정판을 골절 부위보다 1-2 mm 더 크게 재단 후 overlay 방식으로 위치시키는 속눈썹 밑 접근법을 이용하였다. 안와골 하측벽 후방에 골절이 발생하여 속눈썹 밑 접근법으로 시야 확보가 어려운 경우에는 Caldwell-Luc 접근법을 추가로 이용하였다. 상구순 밑 절개를 통하여 상악 동 안에서 골절편 및 상악동으로 탈출된 안와 조직을 밀어 올려서 교정하였다.

\section{통계 분석}

통계 분석은 SPSS version 21 (IBM Corp., Armonk, NY, USA)을 이용하여 범주형 변수 비교에는 chi-square test를 이용하였고, 그 중 변수가 5 이하인 것이 있을 경우에는 Fisher's exact test (양측검정) 방법으로 분석하였다. 통계적 유의 수준은 $95 \%$ 이상 $(p$-value< $<.05)$ 으로 하였다.

\section{결 과}

전체 22명 중 남자가 20명(90.9\%), 여자가 2명(9.1\%)으로 수상 당시 연령은 6-18세까지 평균 14.2 \pm 3.2 세로 13-18세 그룹이 16 명(72.8\%)으로 대다수를 차지했다. 골절 부위는 하 벽이 21예(95.5\%)로 가장 많았으며, 하벽과 내벽 골절이 함께 있는 경우가 1예(4.5\%) 였다. 골절의 원인으로는 타격 또는 폭 행에 의한 경우가 15 예(68.2\%)로 가장 많았으며 낙상에 의한 경우가 7예(31.8\%) 였다(Table 1).

술전 증상으로 16 예의 환자에서 복시, 19예의 환자에서 안 구운동장애, 5 예의 환자에서 구역 및 구토와 같은 눈심장반 사가 관찰되었고, 기타 안와 주위 부종 15 예, 안면부 지각이상 3 예이었다. 술전 안구운동장애, 복시 등의 안과적 증상을 연 령군에 따라 분석하였을 때 6-12세 그룹은 전례, 13-18세 그 룹은 15예(93.7\%)에서 관찰되었다. 수상 당시에는 증상이 경 하였으나 지연성 증상 발현으로 수상 후 16 일, 518일째에 수 술을 시행한 2예의 경우를 제외하고는 골절 수상 후 8일 이 내에 수술을 시행하였으며 기간은 평균 3.65일이었다. 본 연 구에서는 술후 6개월 이상 지속된 증상을 합병증으로 정의하 였는데 복시 4예, 안구운동제한이 3예였으며 연령군과 합병 증 사이에 통계학적으로 유의미한 연관성은 없었다 $(p>0.999)$. 수상 후 수술까지 5일 이내에 조기 수술을 시행한 경우 술후 안과적 합병증이 2예(12.5\%), 5일 이후 수술을 시행한 경우 4예(66.7\%)에서 나타나 유의미한 상관 관계가 있었다 $(p=0.025)$

(Table 2).

16예(72.7\%)는 속눈썹 밑 접근법을, 6예(27.3\%)는 속눈썹 밑 및 Caldwell-Luc 병합 접근법을 시행하였다. 연령군과 접 근법의 통계학적 유의한 연관성은 없었다 $(p=0.634)$. 또한 접

Table 1. Patient demographics $(n=22)$

\begin{tabular}{lc}
\hline \multicolumn{1}{c}{ Variable } & Value \\
\hline Sex & \\
Male & $20(90.9)$ \\
Female & $2(9.1)$ \\
Age $(\mathrm{yr})$ & \\
$6-12$ & $6(27.2), 9.5 \pm 2.2$ \\
13-18 & $16(72.8), 15.9 \pm 1.1$ \\
Fracture site & \\
Medial & $0(0)$ \\
Floor & $21(95.5)$ \\
Medial+floor & $1(4.5)$ \\
Cause of injury & $15(68.2)$ \\
Blow & $7(31.8)$ \\
Fall down & \\
\hline
\end{tabular}

Data are presented as $\mathrm{n}(\%)$ or mean \pm standard deviation 
Table 2. Data of 22 patients with white-eyed orbital blow out fracture

\begin{tabular}{|c|c|c|c|c|c|}
\hline Patient no. & Sex/age & Side & Preoperative symptoms & Trauma to operation time (days) & Lasting symptoms \\
\hline 1 & $M / 15$ & Inf. wall, Lt. & $D, L, N$ & 7 & $\mathrm{~L}$ \\
\hline 2 & $M / 11$ & Inf. wall, Rt. & $D, L$ & 2 & $\mathrm{D}$ \\
\hline 3 & $M / 8$ & Inf. wall, Rt. & $D, L$ & 2 & \\
\hline 4 & $M / 15$ & Inf. wall, Lt. & $D, L$ & 2 & \\
\hline 5 & $M / 13$ & Inf. wall, Rt. & $D, L$ & 5 & \\
\hline 6 & $M / 17$ & Inf. wall, Lt. & $D, L$ & 3 & \\
\hline 7 & $M / 16$ & Inf. wall, Lt. & D & 16 & D \\
\hline 8 & $M / 16$ & Inf. wall, Lt. & $D, L$ & 2 & \\
\hline 9 & $M / 15$ & Inf. wall, Lt. & $D, L$ & 3 & \\
\hline 10 & $M / 16$ & Inf. wall, Lt. & L & 1 & \\
\hline 11 & $M / 16$ & Inf. wall, Lt. & $\mathrm{D}$ & 5 & \\
\hline 12 & $M / 17$ & Inf. wall, Lt. & L & 8 & $\mathrm{~L}$ \\
\hline 13 & $F / 9$ & Inf. wall, Rt. & $D, L$ & 2 & $D, L$ \\
\hline 14 & $M / 18$ & Inf. \& Med. wall, Rt. & $\mathrm{L}$ & 5 & \\
\hline 15 & $M / 16$ & Inf. wall, Lt. & $D, L$ & 7 & \\
\hline 16 & $M / 15$ & Inf. wall, Lt. & $N$ & 7 & \\
\hline 17 & $M / 17$ & Inf. wall, Rt. & $D, L$ & 518 & $D$ \\
\hline 18 & $M / 16$ & Inf. wall, Rt. & $\mathrm{L}$ & 5 & \\
\hline 19 & $M / 12$ & Inf. wall, Rt. & $D, L$ & 5 & \\
\hline 20 & $M / 11$ & Inf. wall, Rt. & $D, L, N$ & 2 & \\
\hline 21 & $M / 17$ & Inf. wall, Lt. & $D, L, N$ & 0 & \\
\hline 22 & $F / 6$ & Inf. wall, Lt. & L, N & 0 & \\
\hline
\end{tabular}

Inf, inferior; Med, medial; D, diplopia; L, limitation of eye movement; N, nausea and vomiting

Table 3. Age group, operation method and trauma to operation time classified by postoperative ocular symptom

\begin{tabular}{lcccc}
\hline \multirow{2}{*}{ Variable } & \multicolumn{2}{c}{$\begin{array}{c}\text { Postoperative ocular } \\
\text { symptoms }\end{array}$} & & \\
\cline { 2 - 3 } & $\begin{array}{c}\text { None } \\
(\mathrm{n}=16)\end{array}$ & $\begin{array}{c}\text { Residue } \\
(\mathrm{n}=6)\end{array}$ & & \\
\hline Age $(\mathrm{yr})$ & $4(66.7)$ & $2(33.3)$ & 6 & \\
$6-12$ & $12(75)$ & $4(25)$ & 16 & \\
$13-18$ & & & & 0.634 \\
Operation method & $11(68.8)$ & $5(31.2)$ & 16 & \\
Subcilliary & $5(83.3)$ & $1(16.7)$ & 6 & \\
Combined* & & & &
\end{tabular}

Trauma to operation time (days)

0.025

$\begin{array}{lrrr}0-5 & 14(87.5) & 2(12.5) & 16 \\ \geq 6 & 2(33.3) & 4(66.7) & 6\end{array}$

Values are presented as $n(\%) . *$ subcilliary+Caldwell-Luc operation

근법에 따른 술후 합병증의 통계학적 유의성은 없었다 $(p=$ 0.634) (Table 3). 2예에서 삽입물에 외안근이 유착되어 재수 술을 시행하였는데 모두 속눈썹 밑 및 Caldwell-Luc 병합 접근법을 시행한 환자에서 발생하였다. 그러나 접근법과 재 수술 사이에 통계학적인 유의한 상관관계는 보이지 않았다 $(p=0.065)$. 골 결손 부위 이식물 종류에 따라 흡수성 판(absorbable plate) 이용한 경우 19예, 골절 부위가 작아서 끼여
있는 외안근 교정후 이식물을 넣지 않은 경우가 3예였다. 공 여 부위 합병증으로 1 예에서 급성 상악동염이 생겼으나 항생 제 투여 후 호전되었다.

\section{고 찰}

소아의 안와 외상은 성인과 다른 특성을 보인다. 소아는 골 의 유연성, 완전히 융합되지 않은 봉합선, 성인에 비해 두꺼운 골막, 광대뼈 주변의 풍부한 연조직으로 인해 강한 충격에도 골구조에 적은 손상을 입는다. ${ }^{3)}$ 안와 내벽은 하벽에 비해 더 얇으나, 내벽은 사골동의 중앙 보강으로 인해 골절이 적게 일 어나 4\%-12\%의 안와 골절 만이 내벽에 발생하여 하벽 골절 이 흔히 발생하는 것으로 보고하고 있다." 따라서 소아 안와 골절에서 하벽의 뚜껑문 골절 및 외안근 및 주위 연조직 감 돈이 가장 흔한 것으로 알려져 있으며 ${ }^{5)} \mathrm{de} \operatorname{Man}$ 등 $^{6)}$ 은 소아 안와 하벽 골절 환자 15 명 중에 14 명이 뚜껑문 골절이라고 보고하였다. 1998년 John 등은 주로 18세 이하 소아 및 청소 년에서 안구 주위 외상 후, 안구 연부조직의 부종, 반상 출혈 등이 심하지 않으나 외안근이 골절편 사이에 끼어 있어 안구 운동 장애와 함께 통증을 호소하는 경우를 white-eyed 안 와 외향 골절로 정의하였다. ${ }^{1)}$ 
White-eyed 안와 외향 골절은 진단하기 힘든 경우가 많다. 첫째, 소아에서 성인에 비하여 안와 주변 부종 및 피하 출혈 과 같은 연조직 손상이 적거나 거의 없는 경우가 있고, 또한 안와 주변 부종도 빠르게 해소되어 안와 골절에 대해 간과하 기가 쉽다(Fig. 1). ${ }^{7)}$ 둘째, 눈심장반사는 외안근이 골절편 사 이에 끼이거나 안구 내 압력이 상승할 때 발생하는 심장 반사 로서 구토와 함께 서맥을 일으키고 때론 심정지에 이르기도 한다. 이런 증상은 외상 진료 시 임상의에게 두개 내 손상 등 을 먼저 의심하게 하여 white-eyed 안와 외향 골절의 진단이 늦어지게 된다. 셋째, 안면부 전산화단층촬영에서 골절 소견 이 경미한 경우가 많으며 골절부가 작아 안구 연부 조직의 감 돈이 영상에서 거의 보이지 않는 경우 발견하기가 매우 어렵 다(Fig. 2).

일반적인 안와 골절에서는 안구 연부조직의 부종이 해소되 는 7-14일 정도 기다려 수술을 시행하지만 white-eyed 안와 외향 골절은 24-48시간 이내의 조기에 수술적 치료를 해야 좋은 결과를 얻을 수 있다고 알려져 있다. 근육이나 조직이 감돈되어 있는 뚜껑문 골절의 경우 외안근의 허혈손상이 나 타나게 되고, 이를 교정하지 않으면 외안근 섬유화 등의 비가 역적인 변화가 발생할 수 있으므로 48시간 이내 즉시 수술을 원칙으로 하고 있다. ${ }^{48)}$ 또한 white-eyed 안와 외향 골절을 수상 후 48시간 이내 조기에 외과적 치료를 받은 환자군은 복시 회복에 평균 1.5 개월 미만, 수술이 48시간 이후에 지연
되어 시행되었을 때 평균 5 개월 이상의 시간이 소요되어 회복 시간에도 차이가 있는 것으로 보고되었다." 반면에 Yang 등미 은 적절한 수술을 통해 감돈된 조직이 완전히 정복된다면 24시간 이내, 24-72시간 사이, 72시간 이후에 수술한 환자군 간의 유의한 통계학적 차이가 없다고 보고하기도 하였다. 본 연구에서는 5 일 이내 수술한 경우 술후 합병증이 적게 나타 났으며 통계적 유의성이 있었다.

수상 원인으로 폭력 및 둔상, 교통사고, 낙상 등이 보고되 었으며, 그 중에서도 폭력이 가장 흔한 원인으로 알려져 있 다. ${ }^{11)}$ 본 연구에서는 폭력 및 둔상, 낙상 순으로 나타났는데, 6-12세 연령군에서는 둔상과 낙상이 비슷한 수로 나타났으 나 13-18세 연령군에서는 폭력 및 둔상이 낙상보다 더 많이 발생하였다. 수술 방법으로 본 연구에서는 주로 속눈썹 밑 접 근법(72.7\%)을 사용하여 수술하였는데 속눈썹 밑 접근법은 전방에 발생한 하벽 안와 골절의 꼬임을 푸는 데 유용하다. 하지만 하벽 재건 이식편을 삽입하기 위해서 골절선 주위 연 조직을 모두 박리해야 하는 단점이 있다. ${ }^{12)}$ 경상악동 접근법 은 전방에 발생한 골절부 정복 시 수술 시야 및 기구 조작에 제한점이 있으나 후방 안와의 심한 골절 정복에 임상적인 유 용성이 있다. 하지만 경상악동 접근법 단독으로는 끼여있는 안구조직을 해결하기가 힘들기 때문에 단독으로 사용하기에 는 제한사항이 있다. ${ }^{13)}$ 통계학적으로 의미는 없었으나, 전체 22예 중 속눈썹 밑 접근법과 경상악동 접근법을 동시에 시행
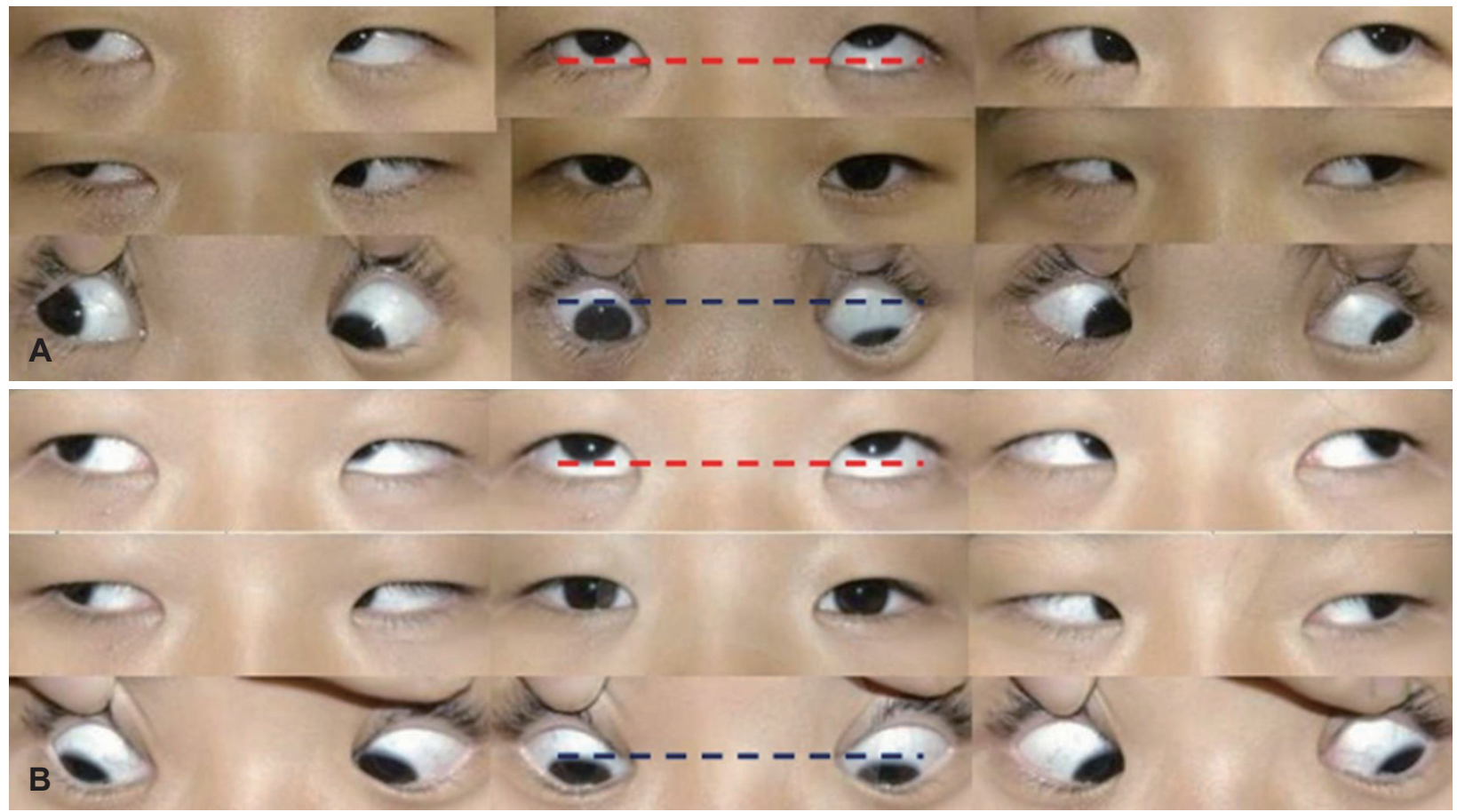

Fig. 1. Preoperative and postoperative 9 cardinal position of gaze. A: Restriction of upward (red line) and downward (blue line) gaze in the right eye with no evidence of periocular soft tissue trauma. B: 3 months after operation shows partial improvement of extraocular movement. 

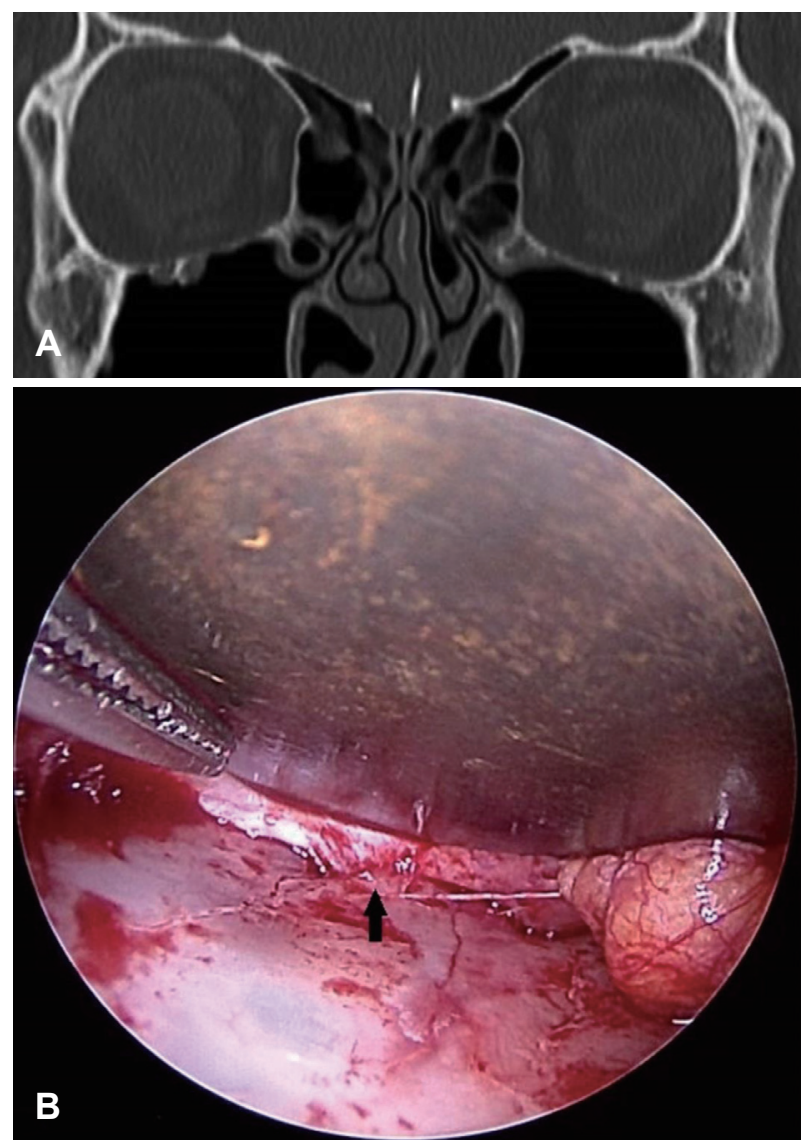

Fig. 2. Preoperative image and intraoperative local finding in the same patient. A: Preoperative orbital CT demonstrates no definite fracture line or extraocular muscle entrapment. B: Intraoperative endoscopic finding shows entrapment of the inferior rectus muscle (arrow) in fracture line.

한 병합 접근법 2예에서만 술후 유착으로 복시가 생겨 재수 술을 시행하였다 $(p=0.065)$. 본원에서는 안와 골절의 부위가 후방부위일 때 병합수술을 이용해서 교정했었고, 이것으로 판단해 볼 때 후방부위 골절에서는 재유착을 방지하기 위해 서 좀 더 확실한 시야 확보와 정확한 위치에 이식물을 삽입 하는 것이 중요할 것으로 생각된다.

앞서 살펴본 바와 같이 white-eyed 안와 외향 골절은 임상 적 증상과 영상의학적 소견이 명확하지 않아 경험이 부족한 임상의는 진단이 지연되어 수술 시기를 놓치는 경우가 많다. 따라서 소아 외상 환자를 다루는 임상의는 white-eyed 안와 외향 골절이 의심이 될 경우 경과 관찰을 하기보다는 보다 적 극적으로 수술적 치료를 고려하는 것이 보다 나은 결과를 얻 을 수 있는 방법임을 견지해야 한다.

\section{Acknowledgments}

None.

\section{Author Contribution}

Conceptualization: all authors. Data curation: Gyo Han Bae, Geun Woo Park, Tai Jung Park, Woong Jae Noh. Formal analysis: Woong Jae Noh, Tae Young Jung. Funding acquisition: all authors. Methodology: Gyo Han Bae, Tae Young Jung. Project administration: Gyo Han Bae, Tae Young Jung. Resources: Gyo Han Bae, Tai Jung Park, Woong Jae Noh. Supervision: Woong Jae Noh, Tae Young Jung. Validation: all authors. Visualization: Gyo Han Bae. Writing — original draft: Gyo Han Bae. Writing—review \& editing: Geun Woo Park, Tai Jung Park, Woong Jae Noh, Tae Young Jung.

\section{ORCIDs}

Tae Young Jung https://orcid.org/0000-0001-9029-2075

Tai Jung Park https://orcid.org/0000-0002-2622-0138

\section{REFERENCES}

1) Jordan DR, Allen LH, White J, Harvey J, Pashby R, Esmaeli B, Intervention within days for some orbital floor fractures: The whiteeyed blowout. Ophthalmic Plast Reconstr Surg 1998;14(6):379-90.

2) Alcalá-Galiano A, Arribas-García IJ, Martín-Pérez MA, Romance A, Montalvo-Moreno JJ, Juncos JM. Pediatric facial fractures: children are not just small adults. Radiographics 2008;28(2):441-61.

3) Cobb AR, Jeelani NO, Ayliffe PR. Orbital fractures in children. Br J Oral Maxillofac Surg 2013;51(1):41-6.

4) Tse R, Allen L, Matic D. The white-eyed medial blowout fracture. Plast Reconstr Surg 2007;119(1):277-86.

5) Wei LA, Durairaj VD. Pediatric orbital floor fractures. J AAPOS 2011;15(2):173-80.

6) de Man K, Wijngaarde R, Hes J, de Jong PT. Influence of age on the management of blow-out fractures of the orbital floor. Int J Oral Maxillofac Surg 1991;20(6):330-6.

7) Kwon JH, Moon JH, Kwon MS, Cho JH. The differences of blowout fracture of the inferior orbital wall between children and adults. Arch Otolaryngol Head Neck Surg 2005;131(8):723-7.

8) Koltai PJ, Amjad I, Meyer D, Feustel PJ. Orbital fractures in children. Arch Otolaryngol Head Neck Surg 1995;121(12):1375-9.

9) Kim NH, Kang SJ. Correlation between the time to surgery and that to recovery from postoperative diplopia based on a single-center, retrospective experience: A case series of 11 patients. Arch Plast Surg 2014;41(5):486-92.

10) Yang JW, Woo JE, An JH. Surgical outcomes of orbital trapdoor fracture in children and adolescents. J Craniomaxillofac Surg 2015; 43(4):444-7.

11) Kwon YH, Park DW, Chung JY, Ahn HB. A clinical study of pediatric orbital wall fracture. J Korean Ophthalmol Soc 2006; 47(1):7-12.

12) Converse JM, Smith B, Obear MF, Wood-Smith D. Orbital blowout fractures: A ten-year survey. Plast Reconstr Surg 1967;39(1):20-36.

13) Otori N, Haruna S, Moriyama H. Endoscopic endonasal or transmaxillary repair of orbital floor fracture: A study of 88 patients treated in our department. Acta Otolaryngol 2003;123(6):718-23. 